\title{
Atypical Herpetic Viral Posterior Uveitis: Non-necrotising Retinitis and Focal Retinitis
}

\author{
Dicle Hazirolan', Gulten Sungur ${ }^{1}$ \\ 'Health Sciences University, Ankara Training and Research Hospital, Ophthalmology Department, Ankara, Turkey
}

Article Info

Article Notes

Received: March 20, 2019

Accepted: June 13, 2019

\section{*Correspondence:}

Dr. Dicle Hazirolan, Health Sciences University, Ankara Training and Research Hospital, Ophthalmology Department, Ankara,

Turkey; Email: dicleoncel@hotmail.com.

(c) 2019 Hazirolan D. This article is distributed under the terms of the Creative Commons Attribution 4.0 International License.

\section{Keywords:}

Posterior viral uveitis

Herpetic uveitis

Retinitis

Focal retinitis

Non-necrotising retinitis

Atypical viral uveitis

Acute retinal necrosis

Progressive outer retinal necrosis

\begin{abstract}
Human herpes viruses are the most common etiologic agents in posterior viral uveitis. They remain latent in the infected host with a risk of reactivation that depends on various factors, including virulence, host immunity, age and comorbidities. Acute retinal necrosis (ARN), progressive outer retinal necrosis (PORN), and CMV retinitis are the most frequent forms. Posterior viral uveitis may occur in atypical clinical entities as non-necrotising herpetic retinitis (NNHR) and focal posterior viral retinitis. The spectrum of herpetic retinopathies might start with focal retinitis, the mildest form, and followed by more severe forms as NNHR, PORN and ARN. The differential diagnosis of atypical viral retinitis is difficult clinically, as it can mimic various kinds of retinitis. The prognosis of the atypical disease is better than other forms of necrotizing retinopathies. A viral etiology must be considered in cases of sightthreatening and atypical posterior uveitis that is unresponsive to conventional corticosteroid treatment.
\end{abstract}

Herpes viruses are the main viral agents which cause posterior segment uveitis. Measles, rubella, and arboviruses such as dengue, West Nile, and chikungunya are also reported to cause posterior uveitis ${ }^{1}$. Many viruses remain latent in the infected host with a risk of reactivation that depends on various factors, including virulence, host immunity, age and comorbidities.

Infections with viruses of the herpes family are common worldwide which can involve any or all ocular tissues, and can cause a wide spectrum of diseases, including uveitis ${ }^{2}$. Only eight known herpes viruses cause infection in humans: herpes simplex virus (HSV) type 1 and 2, varicella zoster virus (VZV), Epstein-Barr virus (EBV), cytomegalovirus (CMV), HSV-6, HSV- 7, and HSV-8. Primary infection of the virus is followed by persistence in the latent form. Reactivation of the virus in the eye may occur in the form of keratitis, anterior uveitis, or retinitis (necrotizing and non-necrotizing). ${ }^{2}$ The clinical manifestations of infection vary from asymptomatic to severe, largely because of the interplay between active viral replication and an exquisite host inflammatory and immune reaction to viral antigens ${ }^{3}$.

Among the spectrum of viral retinitis; acute retinal necrosis (ARN), progressive outer retinal necrosis (PORN), and CMV retinitis have been described previously ${ }^{4-7}$. While ARN occurs in immunocompetent patients, PORN and CMV retinitis are seen in severely immunocompromised patients. Atypical forms of viral retinitis may mimic other retinitis conditions, such as toxoplasmosis, syphilis, aspergillosis, and Behcet disease ${ }^{9}$. The clinical spectrum 
of viral retinitis might start from a mild form like focal retinitis, to a severe form like ARN syndrome.

Acute retinal necrosis syndrome is characterized by peripheral necrotizing retinitis, occlusive retinal arteritis, and a prominent inflammatory reaction in the vitreous and anterior chamber ${ }^{4}$. The earliest retinal lesions are small, patchy, white-yellow areas in the periphery that tend to enlarge and increase in number rapidly and circumferentially ${ }^{10}$. Rapid disease progression is seen in the absence of therapy. Approximately one third of patients develop bilateral involvement, although not always simultaneously ${ }^{11-13}$. In most instances, the patients eye becomes involved within 6 weeks of the onset of symptoms ${ }^{11,12}$. It generally affects healthy and immunocompetent individuals. However, immunocompromised individuals may also develop ARN syndrome ${ }^{14,15}$. VZV is the leading cause of $\mathrm{ARN}^{16}$. Patients with ARN caused by VZV and HSV-1 tend to be older, while HSV-2 is found in younger patients ${ }^{17,18}$. Rarely, ARN may be caused by CMV and EBV ${ }^{16,17,19-22}$.

Progressive outer retinal necrosis is a highly destructive and rapidly progressive variant of ARN, found almost exclusively in immunocompromised individuals, such as AIDS patients with low CD4+T lymphocytes count ${ }^{23-26}$ or post-transplant recipients ${ }^{27-29}$. The disease is bilateral and characterized by multifocal, discrete, white, outer retinal lesions in the posterior pole that progress rapidly to confluence ${ }^{30}$. Unlike ARN syndrome, few or no inflammatory cells are found in the anterior chamber or vitreous, and there is no occlusive vasculitis. PORN is almost exclusively caused by $\mathrm{VZV}^{27,29,30}$.

Cytomegalovirus retinitis is the most common necrotizing retinitis ${ }^{31}$. Unlike ARN syndrome, the clinical course is chronic and indolent with minimal or absent vitreous inflammation ${ }^{32}$. CMV retinitis manifests initially with one or two patches of white granular retinal lesions. These lesions are distributed near retinal vessels, suggesting a hematogenous spread. Active retinitis occurs adjacent to atrophic areas, demonstrating a brush-fire appearance. CMV retinitis is a form of opportunistic viral posterior uveitis that occurs mostly in severely immunocompromised AIDS patients or, rarely, in those on immunosuppressive therapy after organ transplantation, or who are on systemic corticosteroids ${ }^{33-35}$. CMV retinitis usually begins as a unilateral disease, but progresses to involve the contralateral eye within six months in about $20 \%$ of cases, presumably from hematogenous spread ${ }^{36}$.

Margolis et al. ${ }^{37}$ reported a pattern of herpetic retinitis in immunocompetent individuals that affected predominantly the posterior pole. They called this acute retinal disease as multifocal posterior necrotizing retinitis, which shared features both of ARN and progressive outer retinal necrosis. They stated that the disease might have a worse visual prognosis and a higher rate of retinal detachment when compared with ARN.

Besides ARN, PORN and CMV retinitis; posterior viral uveitis can occur in atypical clinical forms. This uncommon and atypical disease entities can be entitled as nonnecrotizing herpetic retinitis (NNHR) which is a relatively new disease reported first in 2003 by Bodaghi and colleagues $^{38}$. The study reported five patients who had PCRconfirmed herpetic infections masquerading as atypical posterior uveitis. The retinitis was chronic in the form of vasculitis which involved retina diffusely. Some of them had mild to moderate vitritis, granulomatous anterior uveitis or papillitis. All the patients were immunocompetent and four had bilateral disease. The initial diagnoses were Behcet disease, birdshot chorioretinopathy and idiopathic vasculitis. As all patients were unreponsive to systemic steroids and/or cyclosporine before the diagnosis of NNHR, anterior chamber tap was performed. The analysis of aqueous humor with PCR detected VZV and HSV-1. All patients were treated well with oral valacyclovir and low dose oral steroids.

Wickremasinge et al. ${ }^{39}$ reported four patients with anterior herpetic uveitis who had arteriolar sheathing in one or more quadrants of retina. VZV was demonstrated in two patients in the vitreous with PCR. Patients responded well to oral acyclovir treatment.

Wensing et al ${ }^{40}$ reported thirteen patients with atypical VZV or HSV uveitis. Four patients demonstrated a slow type, with ARN-like necrotic lesions located in the retinal periphery but characterized by slow progression. Four patients had vasculitis/papillitis, with absence of retinal necrotic lesions, and five patients had panuveitis with lack of necrotic lesions and no obvious vasculitis or papillitis.

Albert et $a l^{41}$ reported two patients with viral uveitis who had occlusive vasculitis with peripheric retinal or optic disc neovascularisation. None of the patients had retinal necrosis.

Matsuo et $a l^{42}$ reported six patients with mild type of ARN syndrome. The patients had peripheral to midperipheral retinitis which extended gradually to the posterior pole and remained isolated without becoming confluent. The lesions resulted in localized retinochoroidal degeneration without retinal detachment.

We reported eight immunocompetent patients with nonnecrotising focal posterior retinitis ${ }^{43}$. All patients had unilateral and unique 1-3 disc diameter sized retinitis foci (except one patient with two foci) which were localized in the posterior pole (Figures 1 and 2). Mild to moderate anterior chamber and vitreous inflammation accompany the retinitis. Four of our patients had been diagnosed with toxoplasma retinochoroiditis and four Behcet's disease previously. Toxoplasma retinochoroiditis is characterized 


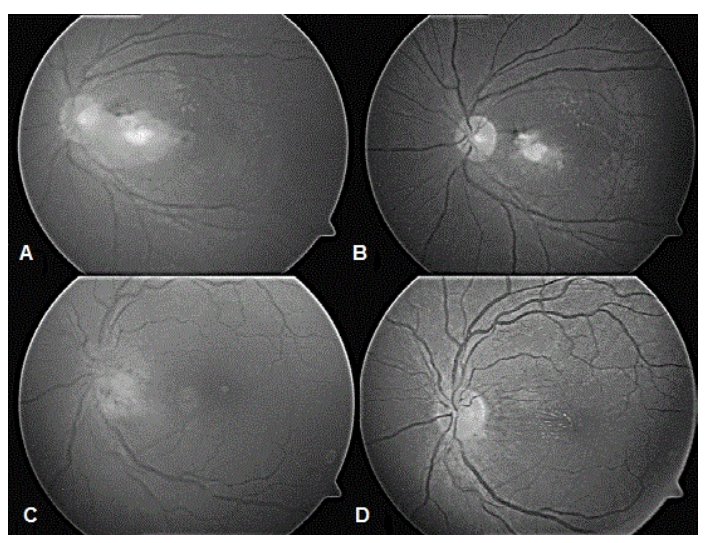

Figure 1: (A) Patient 1: Fundus photo before treatment demonstrating the retinitis on papillomacular bundle.

(B) Patient 1: Fundus photo after treatment.

(C) Patient 3: Fundus photo before treatment showing the juxtapapillary retinitis.

(D) Patient 3: Fundus photo after treatment.

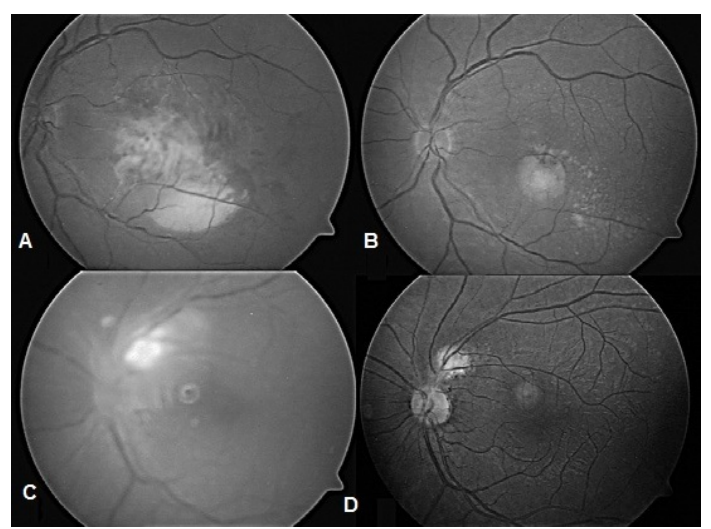

Figure 2: (A) Patient 4: Fundus photo before treatment showing the retinitis on macula.

(B) Patient 4: Fundus photo after treatment.

(C) Patient 6: Fundus photo before treatment demonstrating the parapapillary retinitis.

(D) patient 6: Fundus photo after treatment.

by a focus of yellow-white retinal lesion classically located near an inactive old chorioretinal scar. The retinal lesions in our patients resembled toxoplasma retinochoroiditis, but there was no chorioretinal scar near the active retinitis foci and they did not respond to antitoxoplasmic treatment given previously. Behcet disease is a frequent rheumatic disease in the Mediterranean region involving our country. The most common ocular manifestations are uveitis and retinal vasculitis in Behcet disease. Other systemic components such as oral ulcers, genital ulcers, skin disease, arthritis, thrombophlebitis, and central nervous system disease must be present for the diagnosis. Only one patient had oral ulcer that occurred only once. This frequency of occurrence of oral ulcer is not enough for the diagnosis of Behcet disease. There were no other signs of Behcet disease in the patients. The anterior chamber findings, including the moderate sized keratic precipitates with stellate appearance and raised intraocular pressure in half of our patients during admission, provided clinical clues for a viral ocular infection. The deterioration of symptoms inspite of anti-protozoal or anti-inflammatory treatment in the beginning of the disease supported the viral etiology. Although the diagnosis of viral retinitis is made by clinical findings, PCR analysis of vitreous specimen supported the diagnosis in our patients. According to PCR, 63\% of patients had HSV-1 DNA and 37\% had VZV DNA in the vitreous specimen. According to previous publications, VZV was reported as the most common etiologic agent of viral retinitis ${ }^{38,44}$. We found HSV-1 as the most common agent in focal retinitis in our study. Polymerase chain reaction analysis of vitreous biopsy specimens was used for accurate diagnosis of the disease in our study. Rothova and colleagues also reported a high frequency of positive results with PCR analysis of aqueous humor in patients with suspected infectious uveitis located in the posterior segment of the eye ${ }^{45}$. According to this article, aqueous humor sampling instead of vitreous biopsy, which is a more invasive method, may also be preferred in the diagnosis of viral retinitis. In our study, all patients received intravenous acyclovir followed by oral acyclovir for eight months in average with tapering doses. The viral retinitis described in our study is different from other cases of atypical viral retinitis reported in the literature. Retinal lesions are smaller and focally situated in the posterior pole without progression with antiviral treatment.

Viral retinopathies might be accepted as a continuous spectrum of diseases, based on the studies mentioned above. The clinical presentation of a particular pattern might depend on the patient's immune status. Our patients with focal posterior viral retinitis may be located at the starting point of the spectrum of herpetic retinopathies and constitute the mildest form of the disease. Table. 1 summarizes non-necrotising herpetic retinitis reported in the literature. This spectrum may be followed by mild ARN syndrome $^{46}$, non-necrotising herpetic retinitis ${ }^{38}$, multifocal posterior necrotizing retinitis ${ }^{37}$, progressive outer retinal necrosis, and ARN.

The differential diagnosis of atypical viral retinitis is difficult clinically as it can mimic various kinds of retinitis. The prognosis of the disease is better than other forms of necrotizing retinopathies that involve a larger area of the retina. Thus, atypical forms of viral retinitis must be considered in the differential diagnosis of retinitis. A viral etiology must be considered in cases of sight-threatening and atypical posterior uveitis that is unresponsive to conventional corticosteroid treatment ${ }^{38}$.

The different clinical forms of viral retinitis might be related to the number of viruses present in the eye and the status of the immune response of the host. Although ARN has been thought to occur predominantly in immuno- 
Table 1. Summary of non-necrotising herpetic retinitis cases.

\begin{tabular}{|c|c|c|c|c|c|c|c|c|c|}
\hline $\begin{array}{l}\text { Author } \\
\text { (Year) }\end{array}$ & $\begin{array}{c}\text { Number of } \\
\text { patients }\end{array}$ & $\begin{array}{l}\text { Age } \\
\text { (Years) }\end{array}$ & $\begin{array}{c}\text { Gender } \\
\text { Male/female }\end{array}$ & $\begin{array}{c}\text { Laterality } \\
\mathrm{N}(\%)\end{array}$ & $\begin{array}{l}\text { Immuno-de- } \\
\text { ficiency N(\%) }\end{array}$ & $\begin{array}{c}\text { Viral etiology } \\
N(\%)\end{array}$ & $\begin{array}{l}\text { Method of } \\
\text { diagnosis }\end{array}$ & Clinical findings & Treatment \\
\hline $\begin{array}{l}\text { Bodaghi et.al. } \\
(2003)^{33}\end{array}$ & 5 & $55(29-82)$ & $1 / 4$ & $\begin{array}{c}\text { Unilateral } \\
(60 \%)\end{array}$ & 0 & $\begin{array}{l}\text { HSV-1:2 } \\
\text { VZV: } 3\end{array}$ & $\begin{array}{l}\text { Anterior } \\
\text { chamber } \\
\text { tap }\end{array}$ & $\begin{array}{l}\text { Vitritis, vasculitis, } \\
\text { and/or papillitis }\end{array}$ & $\begin{array}{l}\text { Oral valacyclovir, } \\
\text { oral steroid }\end{array}$ \\
\hline $\begin{array}{l}\text { Hazirolan } \\
\text { et.al. } \\
(2010)^{43}\end{array}$ & 8 & $32(22-42)$ & $4 / 4$ & $\begin{array}{c}\text { Unilateral } 8 \\
(100 \%)\end{array}$ & 0 & $\begin{array}{l}\text { HSV-1: } 5 \\
\text { VZV:3 }\end{array}$ & $\begin{array}{l}\text { Vitreous } \\
\text { tap }\end{array}$ & $\begin{array}{l}\text { Non-necrotising, } \\
\text { focal retinitis in the } \\
\text { posterior pole with } \\
\text { mild vitritis }\end{array}$ & $\begin{array}{l}\text { Systemic acyclovir, } \\
\text { oral corticosteroid }\end{array}$ \\
\hline $\begin{array}{l}\text { Wensing } \\
\text { et.al. } \\
(2011)^{40}\end{array}$ & 9 & $55(19-81)$ & $6 / 3$ & $\begin{array}{l}\text { Unilateral } \\
(78 \%)\end{array}$ & $\begin{array}{l}\text { Not-men- } \\
\text { tioned }\end{array}$ & $\begin{array}{l}\text { HSV-1:2 } \\
\text { VZV: } 7\end{array}$ & $\begin{array}{c}\text { Anterior } \\
\text { chamber } \\
\text { or vitreous } \\
\text { tap }\end{array}$ & $\begin{array}{l}\text { Vitritis, vasculitis, } \\
\text { and/or papillitis ( } 4 \\
\text { patients), or panu- } \\
\text { veitis without any } \\
\text { distinct features ( } 5 \\
\text { patients). None } \\
\text { had other retinal } \\
\text { lesions. }\end{array}$ & Systemic antivirals \\
\hline $\begin{array}{l}\text { Albert et.al. } \\
(2015)^{41}\end{array}$ & 2 & $15(11-19)$ & $1 / 1$ & $\begin{array}{c}\text { Bilateral } \\
(100 \%)\end{array}$ & 0 & $\begin{array}{l}\text { HSV-1: } 1 \\
\text { VZV: } 1\end{array}$ & $\begin{array}{l}\text { Anterior } \\
\text { chamber } \\
\text { and vitre- } \\
\text { ous tap }\end{array}$ & $\begin{array}{l}\text { Non-necrotizing } \\
\text { retinopathy with } \\
\text { occlusive vasculitis } \\
\text { with } \\
\text { early retinal neo- } \\
\text { vascularization. }\end{array}$ & $\begin{array}{l}\text { Oral acyclovir, oral } \\
\text { corticosteroid }\end{array}$ \\
\hline
\end{tabular}

competent individuals, a decline in cellular immunity might be present in these patients ${ }^{47-49}$. According to this hypothesis, focal viral retinitis, non-necrotizing viral retinitis and mild ARN occur in patients who have better functioning cellular immunity than patients with full-blown ARN. This hypothesis needs to be further investigated with immunological studies.

\section{References}

1. Lee JH, Agarwal A, Mahendradas P, et al. Viral posterior uveitis. Surv Ophthalmol. 2017; 62(4): 404-445.

2. Gaynor BD, Margolis TP, Cunningham ET. Advances in diagnosis and management of herpetic uveitis. Int Ophthalmol Clin. 2000; 40: 85109.

3. Pepose JS. Herpes simplex keratitis: role of viral infection versus immune response. Surv Ophthalmol. 1991; 35: 345-52.

4. Holland GN. Executive committee of the American Uveitis Society: standard diagnostic criteria for the acute retinal necrosis syndrome. Am J Ophthalmol. 1994; 117: 663-7.

5. Forster DJ, Dugel PU, Frangieh GT, et al. Rapidly progressive outer retinal necrosis in the acquired immunodeficiency syndrome. Am Ophthalmol. 1990; 110: 341-8.

6. Guex-Crosier Y, Rochat C, Herbort CP. Necrotizing herpetic retinopathies: a spectrum of herpes virus-induced diseases determined by the immune state of the host. Ocul Immunol Inflamm. 1997; 5: 259-65.

7. Holland GN, Tufail A, Jordan MC. Cytomegalovirus disease.In: Pepose J, Holland GN, Wilhelmus KE, eds. Ocular Infection and Immunity St Louis Mosby. 1996; 1088-128.

8. Chang $\mathrm{S}$, Young LH. Acute retinal necrosis: an overview. Int Ophthalmol Clin. 2007; 47: 145-54.

9. Balansard B, Bodaghi B, Cassoux N, et al. Necrotising retinopathies simulating acute retinal necrosis syndrome. Br J Ophthalmol. 2005; 89: 96-101.
10. Bonfioli AA, Eller AW. Acute retinal necrosis. Semin Ophthalmol. $2005 ; 20$ : $155-60$.

11. Fisher JP, Lewis ML, Blumenkranz M, et al. The acute retinal necrosis syndrome: part 1: clinical manifestations. Ophthalmology. 1982; 89: 1309-16.

12. Duker JS, Blumenkranz MS. Diagnosis and management of acute retinal necrosis (ARN) syndrome. Surv Ophthalmol. 1991; 35: 327-43.

13. Palay DA, Sternberg P, Davis J, et al. Decrease in the risk of bilateral acute retinal necrosis by acyclovir therapy. Am J Ophthalmol. 1991; 112: $250-5$.

14. Friberg TR, Jost BF. Acute retinal necrosis in an immunosuppressed patient. Am J Ophthalmol. 1984; 98: 515-7.

15. Akova YA, Altan-Yaycioglu R, Yllmaz G, et al. Opportunistic posterior uveal infections in renal transplant patients. Transplant Proc. 2006; 38: 1348-53.

16. Lau CH, Missotten T, Salzmann J, et al. Acute retinal necrosis: Features, management, and outcomes. Ophthalmology. 2007; 114(4): 756-762.

17. Cochrane TF, Silvestri G, Mcdowell C, et al. Acute retinal necrosis in the United Kingdom: results of a prospective surveillance study. Eye. 2012; 26(3): 370-378.

18. Kianersi F, Masjedi A, Ghanbari H. Acute Retinal Necrosis after Herpetic Encephalitis. Case Rep Ophthalmol. 2010; 1(2): 85-89.

19. Hillenkamp J, Nolle B, Bruns C, et al. Acute Retinal Necrosis: Clinical Features, Early Vitrectomy, and Outcomes. Ophthalmology. 2009; 116(10): 1971-5

20. Kramer S. Epstein-Barr virus associated acute retinal necrosis. Br J Ophthalmol. 2001; 85(1): 110d-110.

21. Meghpara B, Sulkowski G, Kesen MR, et al. Long-Term Follow-Up Of Acute Retinal Necrosis. Retina. 2010; 30(5): 795-800.

22. Schaal S, Kagan A, Wang Y, et al. Acute Retinal Necrosis Associated With Epstein-Barr Virus: immunohistopathologic confirmation. JAMA Ophthalmol. 2014; 132(7): 881.

23. Greven CM, Ford J, Stanton C, et al. Progressive Outer Retinal Necrosis 
Secondary To Varicella Zoster Virus In Acquired Immune Deficiency Syndrome. Retina. 1995; 15(1): 14-20.

24. Holland GN. The progressive outer retinal necrosis syndrome. Int Ophthalmol. 1994; 18(3): 163-165.

25. Pavesio CE, Mitchell SM, Barton K, et al. Progressive outer retinal necrosis (PORN) in AIDS patients: A different appearance of varicellazoster retinitis. Eye. 1995; 9(3): 271-276.

26. Tseng CC, Chen SN, Hwang JF, et al. Progressive outer retinal necrosis associated with occlusive vasculitis in acquired immunodeficiency syndrome. J Formos Med Assoc. 2015; 114(5): 469-472.

27. Kalpoe JS, Dehn CEV, Bollemeijer JG, et al. Varicella zoster virus (VZV) related progressive outer retinal necrosis (PORN) after allogeneic stem cell transplantation. Bone Marrow Transplant. 2005; 36(5): 467-469.

28. Khot A, Dignan F, Taylor S, et al. Another case of PORN (bilateral progressive outer retinal necrosis) after allogeneic stem cell transplantation. Bone Marrow Transplant. 2006; 37: 113-114.

29. Turno-Kręcicka A, Boratyńska M, Tomczyk-Socha M, et al. Progressive outer retinal necrosis in immunocompromised kidney allograft recipient. Transpl Infect Dis. 2015; 17(3): 400-405.

30. Austin RB. Progressive outer retinal necrosis syndrome: a comprehensive review of its clinical presentation, relationship to immune system status, and management. Clin Eye Vis Care. 2000; 12: 119-29.

31. Tajunisah I, Reddy SC, Tan LH. Acute retinal necrosis caused by cytomegalovirus in an immunocompetent adult: case report and review of the literature. Int Ophthalmol. 2009; 29: 85-90.

32. Teich SA, Cheung TW, Friedman AH. Systemic antiviral drugs used in ophthalmology. Surv Ophthalmol. 1992; 37: 19-53.

33. Pertel P, Hirschtick R, Phair J, et al. Risk of Developing Cytomegalovirus Retinitis in Persons Infected With the Human Immunodeficiency Virus. Retina. 1993; 13(3): 262-263.

34. Agarwal A, Kumari N, Trehan A, et al. Outcome of cytomegalovirus retinitis in immunocompromised patients without Human Immunodeficiency Virus treated with intravitreal ganciclovir injection. Graefes Arch Clin Exp Ophthalmol. 2014; 252(9): 1393-1401.

35. Kulshrestha MK, Goble RR, Murray PI. Cytomegalovirus retinitis associated with long term oral corticosteroid use. $\mathrm{Br} \mathrm{J}$ Ophthalmol. 1996; 80(9): 849-850.
36. Kempen JH, Jabs DA, Wilson LA, et al. Incidence of Cytomegalovirus (CMV) Retinitis in Second Eyes of Patients With the Acquired Immune Deficiency Syndrome and Unilateral CMV Retinitis. Am J Ophthalmol. 2005; 139(6): 1028-1034.

37. Margolis R, Brasil OFM, Lowder CY, et al. Multifocal posterior necrotising retinitis. Am J Ophthalmol. 2007; 143: 1003-8.

38. Bodaghi B, Rozenberg F, Cassoux N, et al. Nonnecrotizing herpetic retinopathies masquerading as severe posterior uveitis. Ophthalmology. 2003; 110(9): 1737-1743.

39. Wickremasinghe SS, Stawell R, Lim L, et al. Non-necrotizing Herpetic Vasculitis. Ophthalmology. 2009; 116(2).

40. Wensing B, de Groot-Mijnes JD, Rothova A. Necrotizing and nonnecrotizing variants of herpetic uveitis with posterior segment involvement. Arch Ophthalmol. 2011; 129(4): 403-8.

41. Albert K, Masset M, Bonnet S, et al. Long-term follow-up of herpetic non-necrotizing retinopathy with occlusive retinal vasculitis and neovascularization. J Ophthal Inflamm Infect. 2015; 5(1).

42. Matsuo T, Nakayama T, Koyama T, et al. A proposed mild type of acute retinal necrosis syndrome. Am J Ophthalmol. 1988; 105: 579-83.

43. Hazirolan D, Sungur G, Demir N, et al. Focal posterior pole viral retinitis. Eur J Ophthalmol. 2010; 20(5): 925-30

44. Lau CH, Missotten T, Salzmann J, et al. Acute retinal necrosis: features, management, and outcomes. Ophthalmology. 2007; 114: 756-62.

45. Rothova A, de Boer JH, Ten Dam-van Loon NH, et al. Usefulness of aqueous humor analysis for the diagnosis of posterior uveitis. Ophthalmology. 2008; 115: 306-11.

46. Nussenblatt RB, Whitcup SM. Uveitis Fundamentals and Clinical Practice 3rd ed Philadelphia Mosby. 2004: 201-2.

47. Sims JL, Yeoh J, Stawell RJ. Acute retinal necrosis: a case series with clinical features and treatment outcomes. Clin Experiment Ophthalmol. 2009; 37(5): 473-477.

48. Kezuka T, Sakai JI, Usui N, et al. Evidence for antigen-specific immune deviation in patients with acute retinal necrosis: 2001 . Ocul Immunol Inflamm. 2007; 15(3): 241-248.

49. Rochat C, Polla BS, Herbort CP. Immunological profiles in patients with acute retinal necrosis. Graefes Arch Clin Exp Ophthalmol. 1996; 234(9): 547-552. 